\title{
Risk Assessment from Catchment to Consumers as Framed in Water Safety Plans: A Study from Maiduguri Water Treatment Plant, North East Nigeria
}

\author{
Mohammed Mustapha ${ }^{*}$, M. K. C. Sridhar ${ }^{2}$, A. 0. Coker ${ }^{3}$, Ayotunde Ajayi ${ }^{4}$, \\ Abubakar Suleiman5 \\ ${ }^{1}$ Department of Agricultural and Environmental Resources Engineering, Faculty of Engineering, University of Maiduguri, \\ Maiduguri, Nigeria \\ ${ }^{2}$ Departmentof Environmental Health Sciences, Faculty of Public Health, University of Ibadan, Ibadan, Nigeria \\ ${ }^{3}$ Department of Civil Engineering, Faculty of Technology, University of Ibadan, Ibadan, Nigeria \\ ${ }^{4}$ Kelamide-O Nigeria Ltd, Aderibigbe St., Off Halleluya Estate, Osogbo, Osun State, Nigeria \\ ${ }^{5}$ Maiduguri Water Treatment Plant, Operations Department, Maiduguri, Nigeria \\ Email: *mohammedmusty88@gmail.com
}

How to cite this paper: Mustapha, M., Sridhar, M.K.C., Coker, A.O., Ajayi, A. and Suleiman, A. (2019) Risk Assessment from Catchment to Consumers as Framed in Water Safety Plans: A Study from Maiduguri Water Treatment Plant, North East Nigeria. Journal of Environmental Protection, 10, 1373-1390.

https://doi.org/10.4236/jep.2019.1010081

Received: September 9, 2019

Accepted: October 27, 2019

Published: October 30, 2019

Copyright $\odot 2019$ by author(s) and Scientific Research Publishing Inc. This work is licensed under the Creative Commons Attribution International License (CC BY 4.0).

http://creativecommons.org/licenses/by/4.0/

\begin{abstract}
Water safety plan as conceived by WHO can lead to prevention of pollution in each component of water supply chain which leads to ensuring safe drinking water. Risk assessment is one of the key components during the development of water safety plan, achieved by identifying hazardous events and estimating their risk towards implementing control measures. This study reports the risk assessment from catchment to consumers in Maiduguri water treatment plant in Northeast Nigeria. Tools such as the field visits, key informant interviews, questionnaire and water quality monitoring were used to identify the hazards and estimate their risk using semi-quantitative matrix. With the existing control measures, the study showed a total of 33 hazardous events; 5 in catchment, 16 in treatment plant, 6 in distribution system and 6 at consumers' points. The risk score indicated 6 are of medium risk and 9 of high risk. Catchment activities, upgrade of treatment facilities and lack of routine maintenance in the treatment plant, pipeline damages in distribution lines, and consumers' lack of hygiene knowledge and awareness were found to be the major contributory factors which affect the desired quality. Therefore participation and commitment by all relevant stakeholders are fundamental requisite to manage the identified health risks.
\end{abstract}




\section{Keywords}

Water Safety Plan, Hazard Identification, Risk Assessment, Maiduguri Water Treatment

\section{Introduction}

The safety of drinking water supply depends on a number of factors including quality of source water, effectiveness of treatment, integrity of the water distribution that transports water to consumers and the consumers themselves in proper handling of the water [1]. This implies that extensively polluted raw water sources require properly operated and maintained water treatment systems in order to distribute safe water to consumers. Inadequate management of drinking water distribution systems can lead to unsafe water at consumers' point which may lead to water borne illnesses. Safe water delivered at consumers point can also be made unsafe due to improper collection, storage and handling. Therefore, WHO recommends implementing water safety plans (WSP) as the most effective way of guarantying the integrity of the water in each of the components in drinking water supplies system, as presented in Figure 1; catchment, treatment process, distribution systems and final users. Marroquin et al., [2], WHO [3] and Bartram et al., [4] emphasized that:

"The most effective means of securing the safety of a drinking water supply is through the use of a comprehensive risk assessment and risk management approach that encompasses all steps in the water supply from catchment to consumer, such approaches are known as water safety plan."

Water safety plans are promoted and encouraged in the third edition of the WHO (2004) guidelines. The aim of the water safety plan is to protect public health and promote good practices such as preventing or minimizing water source pollution, reducing or removing pollutants through treatment processes and preventing its contamination during its storage, distribution and household connection and handling [4].

\subsection{Catchment}

Catchment protection is the first stage in the production of safe drinking water [5]. When sources are managed effectively, subsequently treatment costs are minimized and risks of exposures resulting from failures in treatment procedures are reduced. The catchment water quality may be affected as a result of land use of the watersheds which causes diffuse and point source pollution [6]. These may include the discharge of wastewater from industries, inflow of chemical fertilizers or livestock wastes and the inflow of domestic wastewater from municipal sources [5]. These activities may lead to progressive deterioration of water quality resulting in the exposure of served populations to health risks if adequate treatment barriers are not implemented before distribution. Hence, 


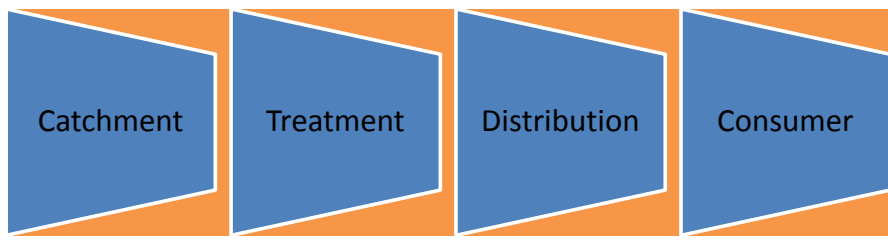

Figure 1. The basic elements in water supply system. (Tool 2.2 adopted from Bartram et al., 2009).

early management of hazardous events at catchment would be an effective preventive measure in relation to water quality incidents in the drinking water supply.

\subsection{Treatment}

Treatment process effectiveness requires proper operation and optimization, such as appropriate dosage of treatment chemicals; following standard operating and maintenance procedures and ensuring that all automated systems are working properly, and not adhering to these leads to contaminated water distributed to consumers. Many outbreaks of diseases have been reported that were due to failures within the treatment plant which could be avoided with simple risk management procedures [7].

\subsection{Distribution}

Systems often receive too little attention despite disease outbreaks due to inadequate management of drinking water distribution systems. A Drinking water treatment plant can provide water that is safe for human consumption but its quality can be affected during movement through the water distribution system before arriving at consumers point [8] [9] [10] the most common faults were cross connections, back siphonages, damage to pipelines, pressure fluctuations, internal and external corrosion in the elements [2] and leakages allowing ingress of contamination which may endanger health of consumers.

\subsection{Consumers}

The aim of water safety plan is not only to identify and improve water quality problems related to catchment, treatment and distribution, but also at consumers point, It was found that water treatment and supply utilities alone cannot ensure the provision of safe drinking water and protection against water borne disease as household plumbing systems, improper storage and handling also cause recontamination [6] [11]. These are attributed to consumers low perception on health risk and lack of knowledge on their responsibility for protecting drinking water quality, which can lead to inappropriate behaviour affecting the integrity of internal distribution system.

The concept of WSPs represent currently the modern system in the delivery of safe water and one of the several stages that is, most likely to be adopted by water industries in the future [12], however, from its inception in 2004 to date, most experience with water safety plan development and implementation has 
been primarily in the developed countries, there is little documented experience of applying WSP in the developing nations [13]. In Nigeria, no information presently appears to be available on research and application of water safety plan despite the municipal water systems' incapability to deliver satisfactory water to consumers [14]. This research work was intended for Maiduguri city, the capital of Borno State in Nigeria. Maiduguri is an arid zone in the northeastern part of Nigeria where on the average of $80 \%$ of the domestic consumers have been facing water shortages daily [15] and outbreaks of cholera, typhoid, and diarrhea occurring annually affecting peoples health and productivity. More recently, Maiduguri recorded outbreaks of cholera resulting in several losses of lives [16] [17].

Whilst there are many sources of drinking water in Maiduguri, Maiduguri water treatment plant is one of the major sources covering about $60 \%$ of the entire metropolis. The integrity of this water supply is constrained by many factors in the catchment, treatment, distribution and consumers endangering the health of consumers. Based on previous studies by Dammo et al., [18] the source water quality parameters exceeded drinking water permissible limits, particularly nitrate $\left(260-230 \mathrm{mg}-\mathrm{NO}_{3} / \mathrm{l}\right)$, phosphate $(22-28 \mathrm{mg} / \mathrm{l})$ and Escherichia coli $(13-24$ $\mathrm{n} / 100 \mathrm{ml}$ ), and Amos et al., [16] found that the treated water from the plant is highly turbid showing $39 \mathrm{NTU} / \mathrm{l}$ and colour showing 40 Hazen scale units/l of which these values were above the specified standards of WHO and NAFDAC (National Agency for Food And Drug Administration and Control). Regarding report on the distribution system and consumers, Aza et al., [19] noticed increased microbial load from treatment plant to the point of delivery to consumers and bacterial growth in some household storage systems which was attributed to improper handling of water. This justifies the present study with a view to supply safe water by Maiduguri water treatment facility through holistic approach from catchment to consumers and development of water safety plan.

The development of Water safety plan and implementation involves eleven modules which are as follows:

Module 1: Assembling the WSP team.

Module 2: Describing the water supply system.

Module 3: Identifying hazards.

Module 4: Assessing control measures and risks.

Module 5: Developing improvement plans.

Module 6: Defining control measure monitoring.

Module 7: Defining verification monitoring.

Module 8: Preparing management procedures.

Module 9: Developing supporting programmes.

Module 10: Planning periodic review of WSP.

Module 11: Revising WSP following incident.

This paper describes the results of risk assessment from catchment to consumers of Maiduguri water treatment plant which may serve as prominent guide for use in the development of the WSP. 


\section{Materials and Methods}

\subsection{Study Area}

\subsubsection{Maiduguri}

Maiduguri, the capital of Borno State is located between latitude $10^{\circ} 00^{\prime}$ and $14^{\circ} 00^{\prime}$ north of the equator and longitude $11^{\circ} 30^{\prime}$ and $14^{\circ} 45^{\prime}$ east of the Greenwich Meridian, the state lies some $355 \mathrm{~m}$ above sea level and it occupies a total area of 50,778 sq km, lying within the Sudan-Sahel zone of Nigeria, it is the largest town in the North-Eastern area of Nigeria. The relief of Maiduguri lies on the vast open plain which is relatively flat or gently undulating. The landscape is developed on the young sedimentary rocks of the Chad formation. This formation is overlain by sand drifts which may be up to 90 meters thick. The extensive plain contains no prominent hill and attains an elevation of about $350 \mathrm{~m}$ above sea level.

The climate is characterized by two distinctive wet and dry seasons, which tend to be controlled by the inter-tropical discontinuity (ITD). The rainy season lasts for about five months (May-October). Available rainfall data reveal that annual rainfall average ranges between $500 \mathrm{~mm}$ and $750 \mathrm{~mm}$ while the intensity of rainfall ranges from $0.002 \mathrm{~mm} / \mathrm{hr}-112 \mathrm{~mm} / \mathrm{hr}$. The mean temperature both seasonally and diurnally varies from $25^{\circ} \mathrm{C}-36^{\circ} \mathrm{C}$, the hottest months being March and April with values between $39.80^{\circ} \mathrm{C}$ and $40.70^{\circ} \mathrm{C}$. The corresponding minimum temperatures of $20.60^{\circ} \mathrm{C}$ and $32^{\circ} \mathrm{C}$ are in December and January.

\subsubsection{Maiduguri Water Treatment Plant}

The Maiduguri water treatment facility was completed in 1986 [15] and is located in Maiduguri metropolis. The treatment plant is one of the major sources of municipal water supply and was designed to treat $67,000 \mathrm{~m}^{3} /$ day and pump $567,8117,676$ litres/day with flow of $775 \mathrm{l} / \mathrm{sec}$, the treatment plant has 32 ground reservoirs each with capacity of $16,750 \mathrm{~m}^{3}, 2$ over head concrete tanks with each capacity of $4500 \mathrm{~m}^{3}, 4$ flat bottom clarifier tanks, rapid gravity sand filters, chemical treatment section, power supply system PHCN and 2 generators of $1275 \mathrm{KVA}$ and high lift pumps [17].

\subsection{Study Design}

The study design was analytical and cross sectional, consisting of laboratory analysis, questionnaire survey, field visits and key informant interviews. Questions for the questionnaire survey were drafted in March 2017 and administered till the middle of April, Key Informant Interviews and site visits were conducted through months of April and May 2017 and continuous even after the sample collection and analysis, risk identification and analysis at the end of May 2017, data entry, results, discussion and conclusion were carried out then.

\subsubsection{Laboratory Analysis}

Water samples were collected from raw water source which was during the early time of the raining season (to determine the source of contamination), through 
various stages of the treatment processes, (to assess the effectiveness of treatment), along the distribution at some selected points where consumers fetch their water (to assess the integrity of distribution) and samples at household taps and storage containers of consumers (to determine the possibility of recontamination from human contact). The samples collected were then subjected to physical, chemical and microbiological analysis to ascertain their quality following standard methods.

1) Parameters measured

a) Physical: turbidity, temperature, electrical conductivity.

b) Chemical: pH, total hardness, total alkalinity, iron, zinc, lead, calcium, potassium, sodium, total dissolved solids, fluoride, chloride, sulphate, residual chlorine, nitrate, phosphate.

c) Microbiological: faecal coliforms and total coliforms counts;in addition presence of some non-coliforms bacteria were also examined.

2) Sampling number and locations

For physical and chemical parameters; a total of five samples were taken for analysis, sampling location and their appropriate labeling are given below:

Sample A: Raw water sample from catchment.

Sample B: Aerated water.

Sample C: Coagulated water.

Sample D: Filtered water.

Sample E: Final treated water.

And for Microbiological analysis, six samples were taken for total coliforms and faecal coliforms count (E. coli), and their locations are:

Sample 1: Final treated water at treatment plant,

Sample 2: 3.5 kilometers away from the treatment plant at Gwange area household tap,

Sample 3: At Gwange area household storage containers, (same house where sample 2 was taken),

Sample 4: $8.5 \mathrm{~km}$ kilometers away from Gwange area at London ciki public tap (end users),

Sample 5: At London Ciki area household storage,

Sample 6: At London Ciki public tap (same point as sample 4).

Note: Sample 4 and 6 were taken at the same location, but the samples were collected at different times; sample 6 was taken after 2 days of non supply (pipes were without water (empty); during this time some ingress of contamination through pipeline holes was seen arising from the open drains where these pipes were laid.).

\section{3) Laboratory procedures}

Laboratory analyses were carried out at four different laboratories for different parameters, namely:

a) Geochemistry lab at Geology Department (University of Maiduguri): Elemental analysis of some of the major Cations ( $\mathrm{Na}, \mathrm{K}, \mathrm{Ca}$, and $\mathrm{Mg}$ ) were analysed using LAQUAtwin meter (Horiba Scientific), and Chloride and Hard- 
ness $\left(\mathrm{CO}_{3}\right.$ and $\mathrm{HCO}_{3}$ determination) using titration, the reagents used for the titration of $\mathrm{CO}_{3}$ and $\mathrm{HCO}_{3}$ determination are Phenolphthalein $1 \%(1 \mathrm{~g}$ of Phenolphthalein in $100 \mathrm{ml}$ alcohol), methyl-orange and $0.1 \mathrm{~N}^{\circ} \mathrm{H}_{2} \mathrm{SO}_{4}$, and for chloride determination are $250 \mathrm{ml}$ conical flask, $\mathrm{K}_{2} \mathrm{CrO}_{4}$ (Potassium Chromate) as indicator and $0.02 \mathrm{~N}$ Silver Nitrate $\left(\mathrm{Ag}_{2} \mathrm{NO}_{3}\right)$.

b) NAFDAC Laboratory in Maiduguri: here total alkalinity were analysed using titrimetry and iron, manganese, zinc, lead, fluoride, sulphate and phosphate analysed using Atomic Absorption Spectrophotometer (AAS, Model AA-6800 SHIM).

c) Veterinary Microbiology Laboratory (University of Maiduguri): the analysis of microbiological parameters of total coliforms and fecal coliform counts were carried out using total coliform count test method and most probable number method respectively. Materials used are EMB (Eosine Methylene Blue B agar) culture media, MacConkey broth, eAger count plate, test tubes and 0.85 percent normal saline solution.

d) Maiduguri Water Treatment Laboratory; parameters analysed were nitrate, total dissolved solids, temperature, electrical conductivity, $\mathrm{pH}$ and turbidity using HI 9829 multi parameter and measurement of residual chlorine using a DPD (Diethyl phenylene diamine) tablet method.

\subsubsection{Consumers' Questionnaire}

The Plant distribute Water to 20 areas within Maiduguri town comprising of low income and high income areas, hence 10 households were randomly selected from each area making a total of 200 questionnaires administered, the questionnaire was structured basically to determine the level of awareness of consumers regarding water quality management at their own level to ensure proper collection, storage, handling and usage of water at households, and also to explore the points of views, perceptions and satisfaction level regarding water service delivery both interms of quality and quantity by the Plant. Hence their socio-demographic characteristics, alternative sources of water and related aspects were studied. Information was also collected on whether health issues encountered in the past and present as a result of poor water supply, facts about the regularity of supply to consumers, type of household storage systems used, household treatment methods if any practiced, hygiene awareness and level of hygiene practiced, and also the extent of consumers knowledge regarding the treatment plant were studied.

\subsubsection{Field Visits}

Sanitary inspection visits were conducted for the catchment, treatment plant, and distribution chain and at consumers' points, inspection such as catchment activities, areas surrounding water abstraction points, elements of treatment, structures and facilities of distribution network and household storage systems.

\subsubsection{Key Informant Interviews}

Discussions were conducted with staff of the water works in the various units, 
one (1) person to represent each unit making a total of 6 person interviwed such as from the administrators, Stores, Quality assurance, operations, electrical and mechanical unit, the interview was basically to have in-depth information on the type of water supply system, the operating techniques being applied and the competence of staff in the water works corporation, this helps in understanding of the entire water system towards predicting of some hazards and hazardous events as per the WHO WSP Module 2 guide. Hence information on Raw water source, treatment units/processes, various chemicals used for treatment, storage system, pumps and pumping, distribution system, available documents that describe the system (flow charts, operating techniques, etc.) control measures, previous historical water quality records (hazards events, outbreaks), quality assurance, laboratory, challenges, supporting programs, management procedures, environmental effects, monitoring, availability of trained staff, extend of water safety plan application, relation with the concerned official authorities (state ministries and agencies) were the discussed issues in the interview, the interview was conducted along with site visits for visual inspection which subsequently helps in hazard identification.

\subsection{Risk Assessment}

Risk assessment is one of the key stages during the development of water safety plan. It is achieved by identifying hazards following Modules 3 and estimating their risk as described in Module 4 which allows prioritizing human and financial resources toward improving control measures as a strategy for reducing health risks [2] as part of water safety plan. One of the tools used in estimating risk recommended in the development of water safety plan is the semi-quantitative matrix method [6] which uses a point scale to measure risk of identified hazards in terms of probability of the hazards occurrence (likelihood) and the impact presented if the hazard occurs (consequences) [4]. These matrices are simple, and the results are easy to understand. In addition to risk assessment, these matrices also prioritize the events according to their level of risk, (high, medium, low) helping to optimize existing control measures or the implementation of new measures that reduce risk levels. While assessing the risk, the Study objectives, identified hazards and hazardous events, and estimation of risk presented by the identified hazards and hazardous events.

\subsubsection{Identification of Hazards and Hazardous Events}

In accordance with the study design following Module 3, all the possible visible and hidden hazards that can compromise effective water delivery in terms of water quality and quantity, compliance with regulations, consumers' acceptance and damage to facilities have been looked into thoroughly. The following 3 types of hazards have been looked into:

1) Physical Hazards (Denoted by $P$ in the Matrix).

2) Chemical Hazards (Denoted by $\mathrm{CH}$ in the Matrix).

3) Microbial Hazards (Denoted by M in the matrix). 
The identification was carried out based on site visits for visual inspection; review of the materials used in treatment, structures and facilities of distribution and household storage containers), key informant interviews (assessment of historic information and events, predictive information based on seasonal changes and knowledge of particular aspects of the treatment and supply system) review of consumers' perceptions and water quality analysis results were all included in the hazards identification study.

\subsubsection{Risk Estimation of All Hazards Identified}

For any hazardous event that can give rise to one, two or to all the three types of hazards, the risk associated is analyzed using semi quantitative matrix approach (Table 1) as described in Module 4 with a score range of $(1-9)$ in which the consequences or severity of a particular hazardous event has been rated from 1 to 3 (from the lowest impact to the highest impact), in terms of health-based, adequacy of supplies, damage to structures, compliance with regulations and aesthetics, as in the WHO water safety Plan Development and Implementation Manual [4].

\section{Consequences}

a) Insignificant (no impact): Rating-1.

b) Moderate impact (aesthetics, adequacy of supplies, damage to facilities): Rating-2.

c) Catastrophic or significant impact (public health effect and compliance with regulations): Rating-3.

And the likelihood or frequency of occurrence of a particular hazardous event has been rated from 1 to 3 starting from the highest frequency to the lowest frequency in terms of possibility of the hazard occurring daily, weekly, monthly, seasonally and yearly.

\section{Likelihood}

a) Daily to weekly (almost certain): Rating-3.

b) Monthly to seasonally (possible): Rating-2.

c) Yearly and above (rare): Rating-1.

Table 1. The matrix table used for estimating the risk.

\begin{tabular}{ccccc}
\hline \multirow{2}{*}{ Matrix } & & \multicolumn{3}{c}{ Severity categories } \\
\cline { 3 - 5 } & & I (1) & II (2) & III (3) \\
\cline { 3 - 5 } Likelihood & A (3) & M (3) & H (6) & H (9) \\
Categories & B (2) & L (2) & M (4) & H (6) \\
& C (1) & L (1) & L (2) & M (3) \\
Risk score rating & & Low (<3) & Moderate (3 - 6) & High (>6) \\
\hline
\end{tabular}

Risk analysis definition parameters: Likelihood categories A = daily to weekly (almost certain) $\mathrm{B}=$ monthly to seasonally (possible) C = yearly and above (rare) Severity categories I = significant risk/catastrophic: public health impact or regulation compliance impact, death or illness expected. II = medium: aesthetics or water quantity (consumers acceptance), damage to facilities III = NO impact or insignificant: Risk score categories High risk = urgent management attention needed Moderate risk = management attention needed Low risk = routine procedures and; Colours Low (L): $<3$ (Denoted by Green Colour); Medium (M): 6 - 9 (Denoted by Yellow Colour); High (H): >6 (Denoted by Red Colour). 
The knowledge of consequence and likelihood were derived based on the study design, (water treatment plant staff opinion, past events, previous studies and experience of Operation and Maintenance staff and review of consumers' survey and results of water quality analysis studies)

\section{1) Risk scoring}

Using semi quantitative method shown in Table 1, the risk presented by each hazard was scored against the likelihood and severity of the hazardous event; these were mathematically presented as:

\section{Risk $=$ likelihood $\times$ severity}

First, the risk score was calculated completely ignoring all the control measures (activities or polices applied to mitigate risk) that actually are in place in the water supply system known as raw risk. site visits were conducted to identify the existing control measures and to assess the effectiveness of the control measures (validation), which was done by reviewing the maintenance and monitoring records, water quality results, consumers survey and field inspection. Then risk score was then recalculated and referred as residual risk taking into account all the control measures that exist in the system, keeping check on that particular hazardous event whether the control measure is effective based on the findings from the validation of the control measures, so the severity and frequency of that hazardous event becomes low which ultimately brings down the risk score of that hazardous event.

\section{Results}

As shown in Table 2, a total of 41 hazardous events were identified (7 in catchment, 21 in treatment, 7 in distribution and 6 in consumers), considering no control measures (raw risk) 21 are classified as having a high risk level, 18 as medium risk and 2 have a low risk level, When the existing control measures identified are considered and their effectiveness, the risk level (residual risk) for the events was reduced to 17 events at a high risk level, 16 at medium level and 8 at low level) and of the existing control measures (14) only 5 were effective in reducing the risk level, where for most hazardous event (27) especially at the catchment and consumers there were no existing control measures in place, thus the need for reinforcing existing control measures to improve their effectiveness and/or evaluating new measures in order to reduce risk levels.

The hazardous events with the high risk level were mainly at the catchment and consumers points. At the catchment, hazardous events were associated with socio-economic activities (crop production, cattle rearing, open human defecation, domestic activities and recreations) for which no control measures were present as the catchment is not a protected zone. At consumers point of use most hazardous event were due to lack of hygiene awareness leading to improper collection, storage and handling of waters as revealed by the by questionnaire survey of which all 200 responded. Within the treatment plant, the hazardous events were due to facilities upgrade and maintenance, whereas along the distribution line, damages in drinking water pipes leading to the leakages and ingress 
of contamination were the major threat to effective conveyance of water to consumers. Table 2 presents the results of the risk assessment from catchment to consumers of the Maiduguri water treatment plant.

Table 2. Risk assessment from source to consumers of Maiduguri water treatment plant system.

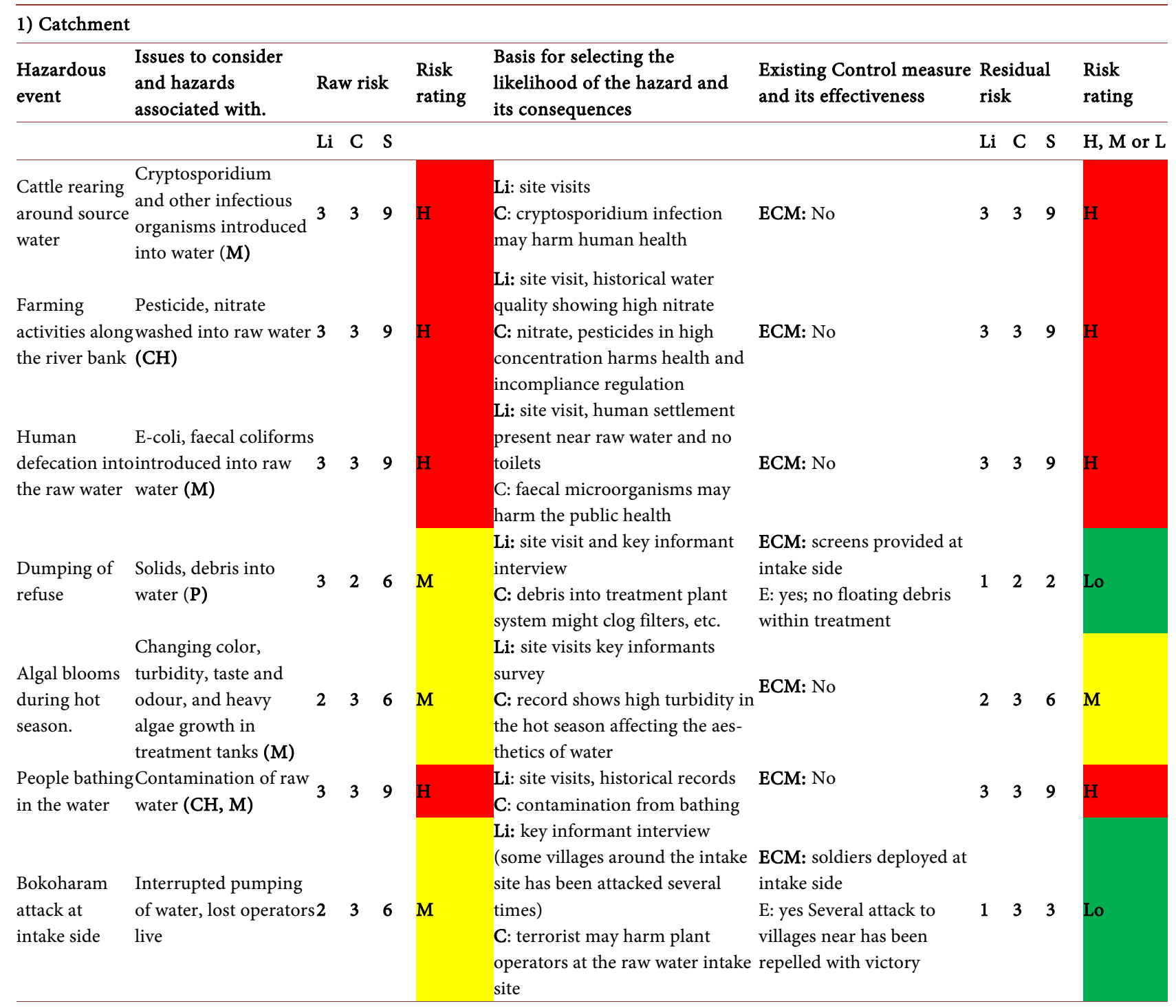

\section{2) Treatment}

\begin{tabular}{|c|c|c|c|c|c|c|c|c|c|c|c|}
\hline $\begin{array}{l}\text { Pre-liming } \\
\text { pump } \\
\text { breakdown }\end{array}$ & $\begin{array}{l}\text { Temporary hardness } \\
\text { and acidity removal } \\
\text { not achieved }\end{array}$ & 3 & 2 & 6 & $\mathbf{M}$ & $\begin{array}{l}\text { Li: site visits, water quality } \\
\text { analysis. } \\
\text { C: imbalance pH causes } \\
\text { corrosion to pipes of treatment } \\
\text { facilities }\end{array}$ & ECM: No & 3 & 2 & 6 & $\mathbf{M}$ \\
\hline $\begin{array}{l}\text { Natural } \\
\text { Aeration } \\
\text { process }\end{array}$ & $\begin{array}{l}\text { Inadequate in } \\
\text { achieving aeration } \\
\text { benefit }(\mathrm{CH})\end{array}$ & 3 & 2 & 6 & $\mathbf{M}$ & $\begin{array}{l}\text { Li: water quality analysis } \\
\text { C: DO, odour and taste not } \\
\text { removed (aesthetics) }\end{array}$ & ECM: No & 3 & 2 & 6 & M \\
\hline $\begin{array}{l}\text { Alum pipe } \\
\text { network } \\
\text { clogging }\end{array}$ & $\begin{array}{l}\text { Interrupted coagulation } \\
\text { treatment }(\mathbf{P}, \mathbf{C H}, \mathbf{M})\end{array}$ & 2 & 3 & 6 & $\mathbf{M}$ & $\begin{array}{l}\text { Li: operators interview (it takes } 6 \\
\text { months before clogging occurs) } \\
\text { C: loss of coagulation leads to } \\
\text { untreated water Supplied to } \\
\text { consumers }\end{array}$ & $\begin{array}{l}\text { ECM: Treatment process is } \\
\text { halted to restore problem } \\
\text { E: Yes }\end{array}$ & 1 & 2 & 2 & Lo \\
\hline
\end{tabular}




\section{Continued}

\begin{tabular}{|c|c|c|c|c|c|c|c|c|c|c|c|}
\hline $\begin{array}{l}\text { Frequent } \\
\text { Alum pumps } \\
\text { break down. }\end{array}$ & $\begin{array}{l}\text { Loss of coagulation } \\
\text { treatment }(\mathbf{P}, \mathbf{C H}, \mathbf{M})\end{array}$ & 2 & 3 & 6 & $\mathbf{M}$ & $\begin{array}{l}\text { Li: it takes } 3 \text { months before it } \\
\text { happens says operators, visual } \\
\text { inspection reveals many broken } \\
\text { alum pumps } \\
\text { C: untreated water supply }\end{array}$ & $\begin{array}{l}\text { ECM: Treatment process is } \\
\text { halted to restore the } \\
\text { problem } \\
\text { E: Yes (but frequent } \\
\text { breakdown need to be } \\
\text { stopped) }\end{array}$ & 2 & 2 & 4 & $\mathbf{M}$ \\
\hline $\begin{array}{l}\text { Trident pipe } \\
\text { clogged }\end{array}$ & $\begin{array}{l}\text { Improper } \\
\text { sedimentation } \\
(\mathbf{P}, \mathrm{CH}, \mathbf{M})\end{array}$ & 3 & 2 & 6 & $\mathbf{M}$ & $\begin{array}{l}\mathrm{Li} \text { : sanitary inspection } \\
\mathrm{C} \text { : leading to contamination }\end{array}$ & $\begin{array}{l}\text { ECM: fishing road is used } \\
\text { to flush it. } \\
\text { E: effective }\end{array}$ & 1 & 2 & 2 & Lo \\
\hline $\begin{array}{l}\text { Trident pipe } \\
\text { breakage }\end{array}$ & $\begin{array}{l}\text { Improper } \\
\text { sedimentation } \\
(\mathbf{P}, \mathbf{C H}, \mathbf{M})\end{array}$ & 2 & 3 & 6 & $\mathbf{M}$ & $\begin{array}{l}\text { Li: sanitary inspection, } \\
\text { discussion with plant operators } \\
\text { C: it reduces the rate of } \\
\text { sedimentation leading to } \\
\text { contamination }\end{array}$ & $\begin{array}{l}\text { ECM: Replacement is done } \\
\text { for any breakage } \\
\text { E: yes }\end{array}$ & 2 & 1 & 2 & Lo \\
\hline $\begin{array}{l}\text { Decantation } \\
\text { pipe } \\
\text { blockage }\end{array}$ & $\begin{array}{l}\text { Inadequate sludge } \\
\text { removal from } \\
\text { sedimentation tank } \\
(\mathrm{P}, \mathrm{CH}, \mathbf{M})\end{array}$ & 1 & 2 & 3 & Lo & $\begin{array}{l}\text { Li: operators interview (blockage } \\
\text { occurrence is very rare) } \\
\text { C: decantation pipe blockage } \\
\text { only flushes sedimentation tank } \\
\text { of flocculated material }\end{array}$ & ECM: No & 1 & 2 & 3 & Lo \\
\hline $\begin{array}{l}\text { Corrosion } \\
\text { and algal } \\
\text { blooms in } \\
\text { sedimentation } \\
\text { tanks }\end{array}$ & $\begin{array}{l}\text { Contamination of } \\
\text { treated water } \\
(\mathrm{CH}, \mathrm{M})\end{array}$ & 3 & 3 & 9 & $\mathrm{H}$ & $\begin{array}{l}\text { Li: visual inspection, water } \\
\text { quality results (increased in } \\
\text { concentration of some water } \\
\text { parameters). } \\
\text { C: contaminated water supply } \\
\text { affects health }\end{array}$ & $\begin{array}{l}\text { ECM: sedimentation tank } \\
\text { is washed every } 90 \text { days } \\
\text { E: no; problems observed } \\
\text { by field visits }\end{array}$ & 3 & 3 & 9 & $\mathrm{H}$ \\
\hline $\begin{array}{l}\text { Frequent } \\
\text { Back washing } \\
\text { Pump failures }\end{array}$ & $\begin{array}{l}\text { Loss of backwashing, } \\
\text { Clogging of filters } \\
\text { which lead to reducing } \\
\text { water quantity and } \\
\text { quality }(\mathbf{P}, \mathbf{C H}, \mathbf{M})\end{array}$ & 3 & 3 & 9 & $\mathrm{H}$ & $\begin{array}{l}\text { Li: discussion with plant } \\
\text { operators reveals that } \\
\text { C: it affects both quality and } \\
\text { quantity of water }\end{array}$ & $\begin{array}{l}\text { ECM: problem is restored } \\
\text { with immediate action } \\
\text { E: Yes but the frequent } \\
\text { break down need to be } \\
\text { curtailed }\end{array}$ & 3 & 2 & 6 & $\mathbf{M}$ \\
\hline $\begin{array}{l}\text { Filter beds } \\
\text { exceeded life } \\
\text { span }\end{array}$ & $\begin{array}{l}\text { Improper filtration } \\
(\mathbf{P}, \mathbf{C H}, \mathbf{M})\end{array}$ & 3 & 3 & & $\mathrm{H}$ & $\begin{array}{l}\text { Li: site visits and discussion with } \\
\text { plant operators, water analysis } \\
\text { results (increased in } \\
\text { concentration of some water } \\
\text { parameters). } \\
\text { C: improperly filtered water } \\
\text { supply to the public }\end{array}$ & ECM: No & 3 & 3 & 9 & $\mathrm{H}$ \\
\hline $\begin{array}{l}\text { Corrosion } \\
\text { and algal } \\
\text { blooms in } \\
\text { Filtration } \\
\text { tanks }\end{array}$ & $\begin{array}{l}\text { Contamination of } \\
\text { water }(\mathbf{C H}, \mathbf{M})\end{array}$ & 3 & 2 & 6 & $\mathbf{M}$ & $\begin{array}{l}\text { Li: site visits and visual } \\
\text { inspection. } \\
\text { C: contaminated supply }\end{array}$ & ECM: No & 3 & 2 & 6 & $\mathbf{M}$ \\
\hline $\begin{array}{l}\text { Leakages in } \\
\text { backwashing } \\
\text { machine } \\
\text { through } \\
\text { gasket }\end{array}$ & $\begin{array}{l}\text { Reducing water } \\
\text { quantity and corrosion } \\
(\mathrm{CH}, \mathrm{M})\end{array}$ & & 2 & 6 & $\mathbf{M}$ & $\begin{array}{l}\text { Li: visual inspection } \\
\text { C: loss of water supply, damage } \\
\text { to facilities }\end{array}$ & ECM: No & 3 & 2 & 6 & M \\
\hline $\begin{array}{l}\text { Head loss to } \\
\text { know when to } \\
\text { back wash. }\end{array}$ & $\begin{array}{l}\text { Loss of signal by } \\
\text { operators the time } \\
\text { required to back wash } \\
\text { filter }\end{array}$ & 3 & 2 & 6 & $\mathbf{M}$ & $\begin{array}{l}\text { Li: visual inspection during site } \\
\text { visit } \\
\text { C: irregular backwashing time. }\end{array}$ & ECM: No & 3 & 2 & 6 & $\mathbf{M}$ \\
\hline $\begin{array}{l}\text { Chlorine } \\
\text { dosing pump } \\
\text { break down }\end{array}$ & $\begin{array}{l}\text { Loss of disinfection } \\
\text { (M) }\end{array}$ & 3 & 3 & 9 & $\mathrm{H}$ & $\begin{array}{l}\text { Li: visual inspection } \\
\text { C: supplying water without } \\
\text { disinfecting affects public health. }\end{array}$ & $\begin{array}{l}\text { ECM: Manual chlorination } \\
\text { E: No (chlorine over } \\
\text { dosing/under dosing } \\
\text { indicated by consumers } \\
\text { survey affecting aesthetics) }\end{array}$ & 3 & 2 & 6 & $\mathbf{M}$ \\
\hline $\begin{array}{l}\text { Post-liming } \\
\text { pump break } \\
\text { down }\end{array}$ & $\begin{array}{l}\text { High acidity of treated } \\
\text { water, corrosion }(\mathrm{CH})\end{array}$ & 3 & 2 & 6 & $\mathbf{M}$ & $\begin{array}{l}\text { Li: visual inspection } \\
\text { C: aesthetics, damage to facilities }\end{array}$ & ECM: No & 3 & 2 & 6 & $\mathbf{M}$ \\
\hline
\end{tabular}




\section{Continued}

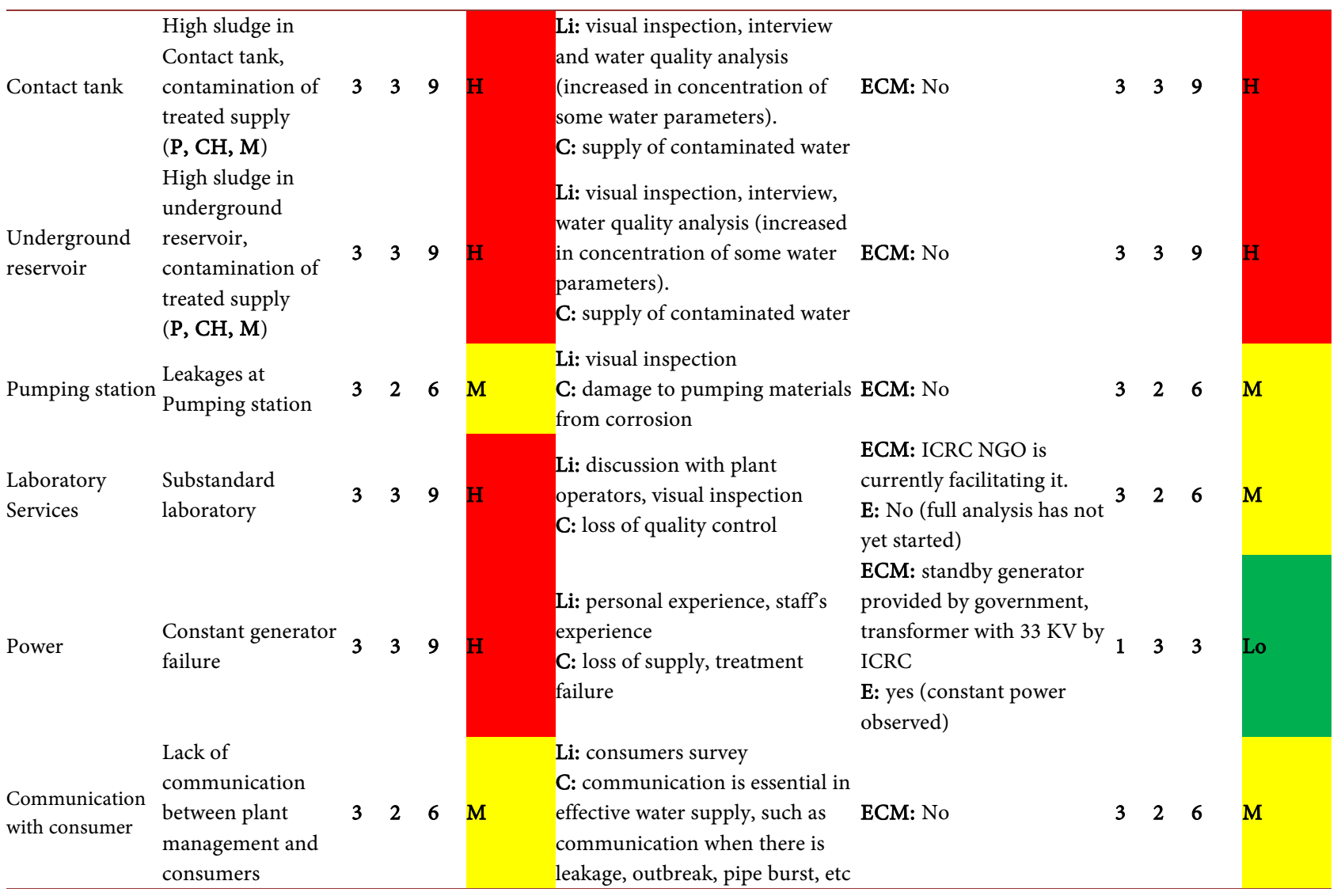

\section{3) Distribution}

Illegal Loss of supply, drop connections in pressure

Loss of water

Leakages quantity, ingress of contamination (P, CH, M)

Pipe bursting Loss of supply, water disaster

Pipes passing Corrosion, Ingress of through contamination from drainage pipe perforations system $\quad(\mathrm{P}, \mathrm{CH}, \mathrm{M})$

Insufficient water Intermittent quantity, ingress of supply contamination from pipe perforations. $\begin{array}{llll}3 & 2 & 6 & \mathrm{M}\end{array}$ M Li: site visits during consumers survey, consumers complaints review ECM: special task force assigned to cut-off any E: No (such connection C: illegal connection affects waterobserved and politics, quantity by reducing pressure sentiments involved) Li: visual inspection during site visit

ECM: repairs by staff C: leakages allow contamination immediately to enter pipe, reduces water $\quad$ E: No; (so many leakages demand, pressure and requires observed in site visits urgent attention

ECM: action is taken

Li: it rarely happens; from plant immediately to control it operators

C: it requires urgent attention

E: Yes; history of pipe burst $1 \quad 2 \quad 2$ is minimal with no serious destruction

Li: visual inspection of sites,

water quality results: high turbidity(12.8NTU) and presence of Pseudomonas aeruginosa in

ECM: No

collected water)

C: public health concern.

Li: consumers survey

C: water quality analysis shows

bacterial contamination from ECM: No

storing water which is a threat to health

\section{$\begin{array}{llll}3 & 2 & 6 & M\end{array}$}

339

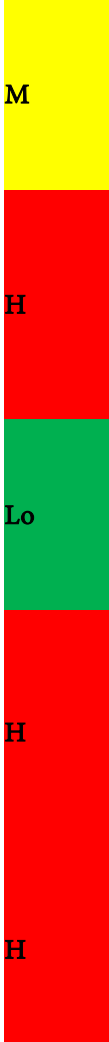




\section{Continued}

\begin{tabular}{|c|c|c|c|c|c|c|c|c|c|c|}
\hline $\begin{array}{l}\text { Gravity } \\
\text { problems }\end{array}$ & $\begin{array}{l}\text { Loss of supply; that } \\
\text { water does not reach } \\
\text { some areas due to drop } 3 \\
\text { in pressure and causes } \\
\text { insufficient water } \\
\text { quantity. }\end{array}$ & 2 & 6 & $\mathbf{M}$ & $\begin{array}{l}\text { Li: site visits, consumers } \\
\text { complain, } \\
\text { C: due to gravity many areas are } \\
\text { getting little or no water. }\end{array}$ & ECM: No & 3 & 2 & 6 & M \\
\hline $\begin{array}{l}\text { Construction } \\
\text { activities }\end{array}$ & $\begin{array}{l}\text { Blockages of pipeline } \\
\text { with construction } \\
\text { debris, breakages of } \\
\text { pipeline allowing entry } \\
\text { of contamination. }\end{array}$ & 2 & 6 & $\mathbf{M}$ & $\begin{array}{l}\text { Li: site visits, customers } \\
\text { complaint } \\
\text { C: loss of supply }\end{array}$ & ECM: No & 3 & & 6 & M \\
\hline
\end{tabular}

\section{4) Consumers}

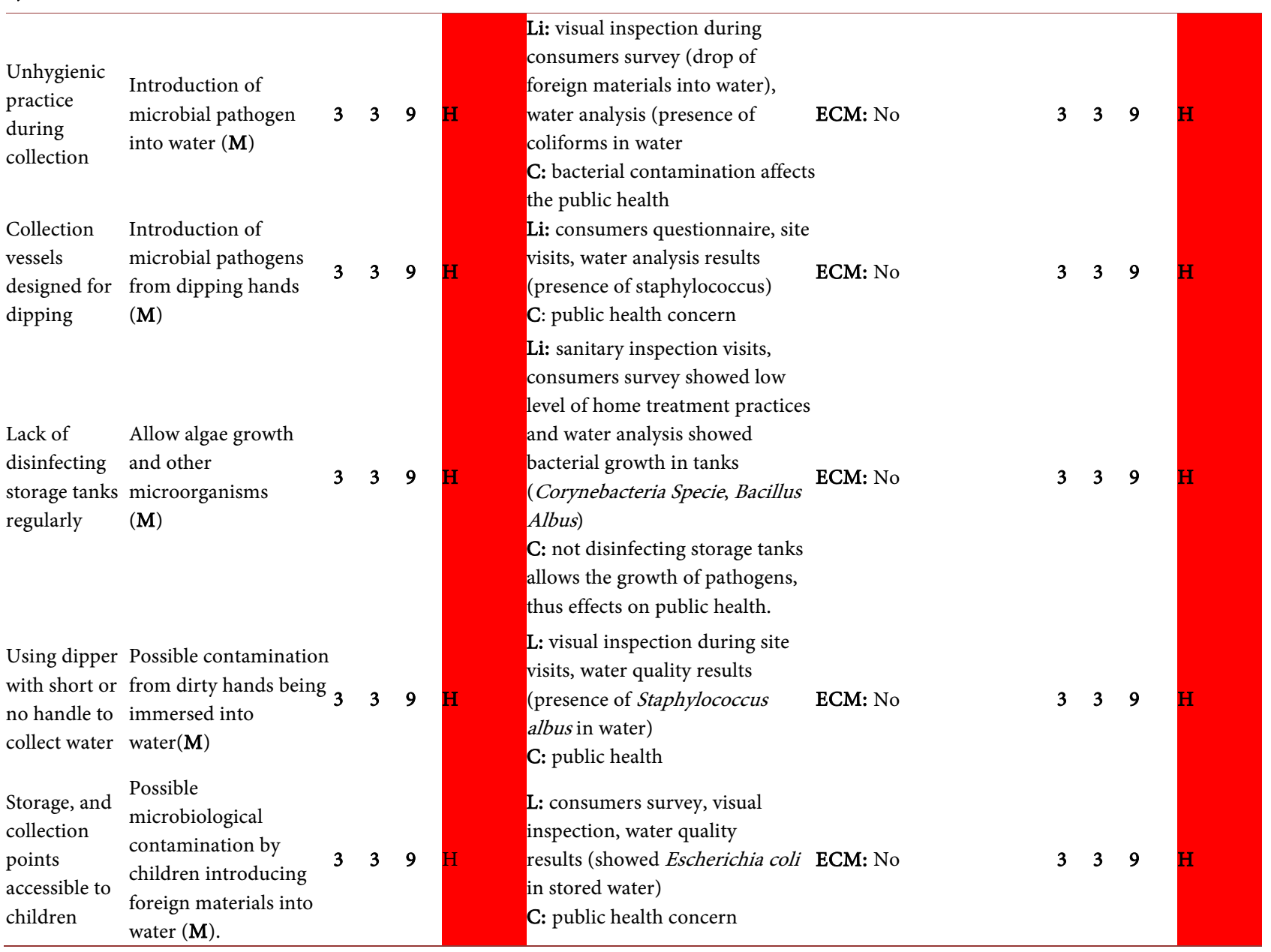

Keys-Lo: Low (denoted by green colour); H: High; Li: Likelihood; C: Consequences; ECM: Existing control measure; E: effectiveness of control measure; M: microbiological hazards; $\mathrm{CH}$ : chemical hazards; P: physical hazards; ICRC: International Committee of Red Cross.

Based on the risk assessment therefore, an improvement plans for the uncontrolled hazardous events which still remain on the higher side even after the control measures installed or with no control measure are being suggested in the proper format as per WSP Module 5, the improvement plans clearly pin point the agencies responsible to execute the plan in a clearly mentioned time frame as shown in Table 3, the plan includes corrective actions such as capital works such as repairs/rehabilitations and maintenance and community awareness programs 
for consumers. The plan includes risk that scored high (Score 6-9) and medium (Score 4-6) on the risk band.

\section{Improvement plan/mitigation measures}

Table 3. Proposed improvement plan for any risk that remains high even after the existing control measures has been installed.

\begin{tabular}{|c|c|c|c|}
\hline Issue identified & Improvement required & Responsibility & Time frame \\
\hline $\begin{array}{l}\text { Farming activities along } \\
\text { the river bed }\end{array}$ & $\begin{array}{l}\text { Agricultural activities in the river bank should be } \\
\text { moved away to some considerable distance away } \\
\text { from the catchment. }\end{array}$ & $\begin{array}{l}\text { State Ministry of Environment, Ministry of } \\
\text { Agriculture, Ministry of Water Resources }\end{array}$ & 1 year \\
\hline $\begin{array}{l}\text { Human defecation into } \\
\text { the raw water }\end{array}$ & $\begin{array}{l}\text { Strictly prohibiting open defecation, } \\
\text { Awareness programs to educate people about proper } \\
\text { sanitary practices, Sanitary toilet should be provided } \\
\text { to people at the catchment }\end{array}$ & $\begin{array}{l}\text { Ministry of Health, State Ministry of } \\
\text { Environment, }\end{array}$ & Uncertain \\
\hline Cattle rearing & $\begin{array}{l}\text { Cattle rearing should be restricted to some } \\
\text { considerable distance away from the raw water } \\
\text { intake side, fencing to restrict them }\end{array}$ & $\begin{array}{l}\text { Ministry of Agriculture, Environment and } \\
\text { Water Resources, }\end{array}$ & 1 year \\
\hline Dumping of refuse & Awareness programs should be conducted & $\begin{array}{l}\text { BOSEPA } \\
\text { LGA (Community Health Officers), NGOs }\end{array}$ & Uncertain \\
\hline Recreational activities & $\begin{array}{l}\text { All recreational activities in and around the raw } \\
\text { water source should be prohibited }\end{array}$ & $\begin{array}{l}\text { Ministry of Tourism and Culture, Water } \\
\text { Resources }\end{array}$ & 6 months \\
\hline Seasonal variation & $\begin{array}{l}\text { Alum dosage should be increased in the treatment } \\
\text { process during hot season and use chemicals such as } \\
\text { copper sulphate to control algae }\end{array}$ & Water treatment plant management & Immediately \\
\hline $\begin{array}{l}\text { Pre-liming pump } \\
\text { breakdown }\end{array}$ & $\begin{array}{l}\text { Brand new, latest and strong pump should be } \\
\text { provided }\end{array}$ & Water treatment plant management & 1 year \\
\hline $\begin{array}{l}\text { Aeration process } \\
\text { ineffective }\end{array}$ & Effective mechanical aerator should be provided & Water treatment plant management & 2 years \\
\hline Alum pumps break down & Latest strong alum pump should be installed & Water treatment plant management & 1 year \\
\hline $\begin{array}{l}\text { Corrosion and algal } \\
\text { blooms in sedimentation } \\
\text { tanks }\end{array}$ & $\begin{array}{l}\text { Always maintain a balanced } \mathrm{pH} \text { in the treatment } \\
\text { systems, use copper sulphate to control algae and } \\
\text { regular cleaning of the tank }\end{array}$ & $\begin{array}{l}\text { Water treatment plant management and } \\
\text { operators }\end{array}$ & Immediately \\
\hline $\begin{array}{l}\text { filter beds exceeded life } \\
\text { span }\end{array}$ & filter beds should be changed completely & $\begin{array}{l}\text { Water treatment plant management and } \\
\text { operators }\end{array}$ & Immediately \\
\hline $\begin{array}{l}\text { Corrosion and algal } \\
\text { blooms in Filtration tanks }\end{array}$ & $\begin{array}{l}\text { Always maintain a balanced } \mathrm{pH} \text { in the treatment } \\
\text { systems, use copper sulphate to control algae }\end{array}$ & $\begin{array}{l}\text { Water treatment plant management and } \\
\text { operators }\end{array}$ & Immediately \\
\hline $\begin{array}{l}\text { Leakages in backwashing } \\
\text { machine through gasket }\end{array}$ & Leakages should be controlled, by sealing the joint & $\begin{array}{l}\text { Water treatment plant management and } \\
\text { operators }\end{array}$ & Immediately \\
\hline $\begin{array}{l}\text { Chlorine dosing pump } \\
\text { break down }\end{array}$ & Latest chlorine pump should be installed & $\begin{array}{l}\text { Water treatment plant management and } \\
\text { operators }\end{array}$ & 6 months \\
\hline $\begin{array}{l}\text { Post-liming pump break } \\
\text { down }\end{array}$ & Latest post liming pump should be installed & $\begin{array}{l}\text { Water treatment plant management and } \\
\text { operators }\end{array}$ & 1 year \\
\hline $\begin{array}{l}\text { Heavy sludge in Contact } \\
\text { tank }\end{array}$ & Should be evacuated completely & $\begin{array}{l}\text { Water treatment plant management and } \\
\text { operators }\end{array}$ & 2 months \\
\hline $\begin{array}{l}\text { Excessive sludge in } \\
\text { Underground reservoir }\end{array}$ & Should be evacuated completely & $\begin{array}{l}\text { Water treatment plant management and } \\
\text { operators }\end{array}$ & 2 months \\
\hline $\begin{array}{l}\text { Leakages at Pumping } \\
\text { station }\end{array}$ & All leakage point should be repaired & $\begin{array}{l}\text { Water treatment plant management and } \\
\text { operators }\end{array}$ & 3 months \\
\hline $\begin{array}{l}\text { Lack of communication } \\
\text { between plant operators } \\
\text { and consumers }\end{array}$ & \multicolumn{2}{|l|}{$\begin{array}{l}\text { Communication system between plant operators and } \\
\text { consumers should be enhanced (through area office) }\end{array}$} & Uncertain \\
\hline
\end{tabular}




\section{Continued}

\begin{tabular}{|c|c|c|c|}
\hline Illegal connections & $\begin{array}{l}\text { Effort should be intensified by cutting off any illegal } \\
\text { connection with no sentiment }\end{array}$ & Water treatment plant management and staff & Immediately \\
\hline Leakages & All leakage point should be repaired & Water treatment plant management & Immediately \\
\hline $\begin{array}{l}\text { Pipes passing through } \\
\text { drainage system }\end{array}$ & $\begin{array}{l}\text { Drainage water should be evacuated on regular basis } \\
\text { before water may reach pipe level, }\end{array}$ & Ministry of Environment & Immediately \\
\hline Intermittent supply & $\begin{array}{l}\text { The design capacity of the plant should increased by } \\
\text { implementing the second phase of the water supply } \\
\text { to ensure constant supply }\end{array}$ & $\begin{array}{l}\text { Ministry of Water Resources, Water treatment } \\
\text { plant management }\end{array}$ & 3 years \\
\hline $\begin{array}{l}\text { Destruction of } \\
\text { underground pipeline } \\
\text { from other activities such } \\
\text { as digging for road } \\
\text { construction, Bridges, } \\
\text { drainage evacuation etc. }\end{array}$ & $\begin{array}{l}\text { All blocked and destroyed pipelines should be } \\
\text { repaired }\end{array}$ & Ministry of Works, Water Resources & 2 years \\
\hline gravity problems & $\begin{array}{l}\text { Design capacity of the plant should be increased by } \\
\text { implementing Second phase of the water supply to } \\
\text { increase pressure so that water may rich consumers } \\
\text { on high hill }\end{array}$ & Ministry of Water Resources & 3 years \\
\hline $\begin{array}{l}\text { Unhygienic practice } \\
\text { during collection }\end{array}$ & $\begin{array}{l}\text { Awareness program should be conducted to educate } \\
\text { consumers }\end{array}$ & Ministry of Education & Uncertain \\
\hline $\begin{array}{l}\text { collection vessels designed } \\
\text { for dipping }\end{array}$ & $\begin{array}{l}\text { Long handle vessels should be distributed to } \\
\text { consumers and encourage them to support the use, } \\
\text { if possible all collection vessels designed for dipping } \\
\text { should be redesigned }\end{array}$ & $\begin{array}{l}\text { Ministry of Water Resources, NGOs, LGA } \\
\text { (Primary Health Care) }\end{array}$ & 3 years \\
\hline $\begin{array}{l}\text { Lack of cleaning storage } \\
\text { tanks regularly }\end{array}$ & $\begin{array}{l}\text { Awareness programs to consumers to clean their } \\
\text { tanks on regular basis }\end{array}$ & $\begin{array}{l}\text { Ministry of Water Resources, NGOs, LGA } \\
\text { (Primary Health Care) }\end{array}$ & Uncertain \\
\hline $\begin{array}{l}\text { Using dipper with short } \\
\text { or no handle }\end{array}$ & Awareness programs & $\begin{array}{l}\text { Ministry of Water Resources, NGOs, LGA } \\
\text { (Primary Health Care) }\end{array}$ & Uncertain \\
\hline $\begin{array}{l}\text { Storage, and collection } \\
\text { points accessible to } \\
\text { children }\end{array}$ & Awareness programs & $\begin{array}{l}\text { Ministry of Water Resources, NGOs, LGA } \\
\text { (Primary Health Care) }\end{array}$ & Uncertain \\
\hline
\end{tabular}

\section{Discussion}

The Maiduguri water supply has been compromised due to several human and natural factors. The raw water supply at the catchment showed high levels of nitrate and faecal pollution as indicated by the presence of $E$. coli. The treated water showed high turbidity and colour. The distribution system showed leakages which resulted in poor quality of the otherwise well treated water. This study has carefully evaluated various hazards and hazardous events together with risk assessment using quantitative risk matrix. Further it was observed that at the consumer end the risk is higher as evident from increased coliforms presumably arising from household sources. In the communities, the hygiene is rather low as children dip their hands and also many of the water drawing cups are indiscriminately kept on floor or other unclean surfaces. From this point of view, the water safety plan comes handy to pin down the factors responsible for unhygienic conditions thereby proffering solutions for better water supply. 


\section{Conclusion}

In this study, risk assessment through evidence based analysis shows the importance of its role as a supporting tool for ensuring water quality, since it identifies the hazardous events, and the analysis of control measures provided evidence of the measures' effectiveness and identified the need for improving existing measures and formulating new measures to generate risk reduction as part of WSP's focus. Therefore, participation and commitment of all stakeholders (water service providers, health, agriculture, water resources and environment entities, consumers, administrators, and catchment community) are fundamental strategies to avoid/reduce health risks by defining appropriate mitigation plans (corrective actions, infrastructures, designs, supporting programs). Some viable mitigation plans are recommended to the water treatment facility (Table 3).

\section{Conflicts of Interest}

The authors declare no conflicts of interest regarding the publication of this paper.

\section{References}

[1] Stevens, M., Howard, G., Davison, A., Bartram, J. and Deere, D. (2004) World Health Organization, Safe Piped Water: Managing Microbial Water Quality in Piped Distribution Systems. IWA Publishing, London.

[2] Marroquin, A.C., Perez-Vidal, A. and Torres-Lozada, P. (2014) Risk Assessment in Water Distribution Systems: Framed in Water Safety Plan. Revista EIA, 11, 155-166.

[3] World Health Organisation (WHO) (2011) Guidelines for Drinking-Water Quality. 4th Edition, WHO, Geneva.

[4] Bartram, J., Corrales, L., Davison, A., Deere, D., Drury, D., Gordon, B., Howard, G., Rinehold, A. and Stevens, M. (2009) Water Safety Plan Manual: Step-by-Step Risk Management for Drinking Water Suppliers. WHO, Geneva.

[5] Sang, L. and Ji, H.W. (2016) Identification of Hazardous Events for Drinking Water Production Process Using Managed Aquifer Recharge in the NAKDONG River Delta, Korea. The Malaysian Journal of Analytical Sciences, 20, 365-372. https://doi.org/10.17576/mjas-2016-2002-20

[6] Andrea, P.V., Ame'zquita-Marroquin, C. and Torres-Lozada, P. (2013) Water Safety Plans: Risk Assessment for Consumers in Drinking Water Supply Systems. Ingeniería y Competitividad, 15, 237-251.

[7] Jetoo, S., Grover, V.I. and Krantzberg, G. (2015) The Teldo Drinking Water Advisory: Suggested Application of the Water Safety Planning Approach. Sustainability, 7, 9797-9808. https://doi.org/10.3390/su7089787

[8] Oloruntoba, E.O. and Sridhar, M.K.C. (2007) Bacteriological Quality of Drinking Water from Source to Household in Ibadan, Nigeria. African Journal of Medicine and Medical Sciences, 36, 169-175.

[9] Onabolu, B., Jimoh, O.D., Igboro, S.B., Sridhar, M.K.C., Onyilo, G., Gege, A. and Ilya, R. (2011) Source to Point of Use Drinking Water Changes and Knowledge, Attitude and Practice in Katsina State Northern Nigeria. Physics and Chemistry of the Earth, 36, 1189-1196. https://doi.org/10.1016/j.pce.2011.07.038

[10] Pooja, D.S., Siddharth, R. and Singh, S. (2015) Assessment of Water Quality. Inter- 
national Journal of Scientific and Engineering Research, 5, 67-70.

[11] Bava, M.T.A. (2015) Development and Implementation of Water Safety Plan in Kondawatuna, Water Supply Scheme, National Water Supply and Drainge Board. 6th International Conference on Structural Engineering and Construction Management, Kandy Sri Lanka, December 2015, 155-162.

[12] World Health Organization (WHO) (2004) Guidelines for Drinking-Water Quality. 3rd Edition, Geneva.

[13] Mahmud, S.G., Abujafar, Shamsudin, S.K., Feroze Ahmed, M., Deere, A.D.D. and Howard, G. (2007) Development and Implementation of Water Safety Plans for Small Water Supplies in Bangladesh. Journal of Water and Health, 5, 585-597. https://doi.org/10.2166/wh.2007.045

[14] Emma, E.E. and Philip, O.P.E. (2014) Water Safety Plan as a Tool for Improved Quality of Municipal Drinking Water in Nigeria. Journal of Environmental Protection, 5, 97-1002.

[15] Umara, B.G., Abdulrahim, A.T., Dibal, J.M. and Shuwa, B.B. (2013) Water Supply Shortage in Maiduguri: An Engineering Point of View. International Journal of Advanced Scientific and Technical Research, 5, 80-87.

[16] Amos, H. and Joshua, E.N. (2014) Assessment of Drinking Water Quality of Alau Dam Maiduguri, Borno State, Nigeria. International Journal of Science and Research, 4.

[17] MSF (Medicins Sans Frontiers) (2014) Nigeria: Outbreak of Cholera in Borno State. http://www.msf.org/en/article/nigeria-outbreak-cholera-borno-state

[18] Dammo, M.N. and Sangodoyin, A.Y. (2014) Socio-Economic Activities around Alau Dam and the Quality of Raw Water Supply to Maiduguri Treatment Plant, Nigeria. Water Practice and Technology, 9, 386-391.

https://doi.org/10.2166/wpt.2014.042

[19] Aza, B., Sugun, M.Y., Musa, J.A. and Turaki, A.U. (2016) Microbial Quality of Water Supplies in Maiduguri Metropolis, North Eastern Nigeria. World Rural Observations, 8, 25-29. 